\title{
The Philosophy of Herbert Hoover: A Contemporary Perspective
}

\section{James S. Olson}

THERE CAN BE LITTLE QUESTION that Herbert Hoover, even forty years after his departure from the White House, remains one of the great mysteries of twentieth century America. During the course of two generations now, historians have reached cursory and usually convenient conclusions about his role in national life; conservatives have canonized him, liberals have villified him, and more recently several New Left intellectuals, including William Appleman Williams and Robert Himmelfarb, have resurrected his reputation and restored him to a prominent position in the pantheon of influential American leaders. ${ }^{1}$ Still, the man remains an enigma, either hated or loved by older Americans, and ignored or curiously disregarded as a high-collared irrelevancy by younger Americans. Nevertheless, his political philosophy is unquestionably germane to modern America, far more relevant today than it was during his own presidency.

Herbert Clark Hoover personified both classical liberalism and the great American dream. During the course of his life he rose from the rural poverty of nineteenth century Iowa to become one of the country's genuinely self-made multimillionaires. This Horatio Alger saga reached a fitting climax in 1928 when Hoover won the right to enter the White House, a pinnacle of international power and prestige. It is little wonder that he cele-

${ }^{1}$ William Appleman Williams, "What This Country Needs . . .", The New York Review of Books, XV (November 5, 1970), pp. 7-8; see the essay by Robert Himmelfarb in Herbert Hoover and the Crisis of American Capitalism, edited by J. Joseph Huthmacher and Warren I. Susman (Cambridge, 1973), pp. 59-85. 
brated America with a genuine patriotism, considering it a truly unique society, one which, over the course of three hundred years, had been able to transcend the traditional social and economic issues which had convulsed Europe and Asia for two millenia. For Hoover, the genius of the United States involved its flexible and fluid social structure, a condition which had liberated the country from the aristocratic class and caste rigidities which had characterized all other societies in all other times. In the absolute terms of both time and space, the United States constituted for Hoover the most magnificent society in the history of the world, for it had achieved a unique synthesis of enlightened individualism and equality of opportunity. Herbert Hoover had constructed his personal philosophy upon the foundation of that unique achievement: "American Individualism" guaranteed to every member of the community uninhibited access to wealth, power and prestige. The only obstacles to success which Hoover's ideal system condoned were incompetence and indolence. For his American Individualism, such matters as race, religion, and national origins were social and political irrelevancies. ${ }^{2}$ Ambition and abilitiy bred success, even insured success. Herbert Hoover was an optimistic activist, and in this sense he articulated the bedrock American ideology of the nineteenth century.

In addition to philosophically ratifying the traditional American egotism, Hoover nurtured a tempered faith in a closely correlated concept: Adam Smith's formulation of entrepreneurial selfinterest. American Individualism enjoyed special distinction for Hoover because it had survived the Industrial Revolution and the evolution of corporate power and interest-group politics. Hoover sincerely believed that economic self-interest and social progress were not necessarily antithetical concepts; indeed, the American standard of living symbolized the successful fusion of self-interest and altruism. One of the truly extraordinary developments of the late nineteenth and early twentieth centuries in the United States had been the rise of economic interest groups throughout the country. These power aggregates in the economic system had

${ }^{2}$ Herbert Hoover, The New Day (Standord, 1928), p. 5; Herbert Hoover, American Individualism (New York, 1922), pp. 9, 41-45; Herbert Hoover, The Ordeal of Woodrow Wilson (New York, 1958), p. viii; Herbert Hoover, America's First Crusade (New York, 1942), pp. 76-79. 
arisen spontaneously to aggrandize their own economic positions by rationalizing control of the national market system, but in the process they had eliminated inefficiency, poor communication, duplication of effort, and destructive competition. Whether they were trade associations, labor unions, farm cooperatives or professional organizations, they represented an attempt to efficiently and profitably coordinate the national economy, in both its productive and distributive dimensions. Despite periodic competitive power struggles between these interest groups, Hoover felt that the dominant thrust of their activities had been cooperative, a blending of self-interest and social philanthropy which had come to provide the ideal environment for the flourishing of individual initiative and equality of opportunity. Though motivated by selfinterest, these economic interest groups were actually led by educated, enlightened men capable of working together to perpetuate American social and economic progress. ${ }^{3}$

But if Hoover's political philosophy celebrated the idea of progress, his historical consciousness prevented him from worshipping any god of inevitability. Herbert Hoover did not naively suppose that the system would always function perfectly, and in this sense, he had departed from the classical tradition. During the previous century of American life, there had simply been too many instances of war, depression and scandal; any belief in American perfection, whether past, present or future, was clearly untenable. He realized that the economic and organizational changes wrought by the Industrial Revolution had altered the structural foundation of laissez-faire. Since the Civil War, the private sector of the United States economy had made enormous gains in production while becoming more and more centralized institutionally. Although Hoover believed that these developments had generally increased the quality of American life, they had also stimulated certain abuses in the system. During those years, the United States had witnessed the evolution of the supercorporation. In several isolated but important instances, they had become alarmingly disdainful of the consuming public; their selfinterest had become counterproductive. By controlling the

${ }^{3}$ Herbert Hoover, American Individualism, pp. 15-17, 49; Herbert Hoover, The Challenge to Liberty (New York, 1934), p. 33; Herbert Hoover, The Memoirs of Herbert Hoover. Volume I. The Years of Adventure, 1874-1920 (New York, 1952), p. 172. 
national marketplace, they had successfully limited competition and prohibited access to economic power by new groups. They had become, in Hoover's mind, an entrepreneurial aristocracy, manipulating the economic system to augment their own wealth, but without giving the least consideration to the national social and economic impact of their activities. For two hundred years American liberalism had attempted to eliminate all artifical impediments to individual opportunity, be they racial, economic or political. A social or economic elite in any form, for Hoover, was contrary to the national historical experience. Indeed, it contradicted American liberalism by compromising individual opportunity. Fortunately, the progressive movement in the earlier years of the twentieth century had institutionalized the regulatory state to counter and control the power of unenlightened economic giants. Herbert Hoover understood and condoned the transition American public policy had made between the laissez-faire liberalism of Thomas Jefferson and Andrew Jackson and the progressive liberalism of Theodore Roosevelt, Herbert Croly, Woodrow Wilson, and Louis Brandeis. Herbert Hoover was an American progressive, perhaps the last American progressive. ${ }^{4}$

Consequently, the political state played a necessary and crucial role in the functioning of Hoover's ideal political economy, for it had become liberalism's partner in the new industrial society. Over the course of his career, Hoover had become a confirmed believer in the decentralization of political power because he felt that political agencies at the grassroots level were better equipped than distant, centralized bureaucracies to evaluate local conditions and to solve local problems. But the rise of the modern, interest-group state, with its nationwide network of economic power, had necessitated the creation of certain centralized political bureaucracies to regulate the new industrial giants. The most powerful of those bureaucracies was the federal government, and

${ }^{4}$ Herbert Hoover, The Challenge to Liberty, p. 6; Herbert Hoover, American Individualism, pp. 8-11, 51-55, 59-60; Herbert Hoover, The Ordeal of Woodrow Wilson, pp. vii-viii, 11; William S. Myers, ed., The State Papers and Other Public Writings of Herbert Hoover. Volume I (New York, 1934), p. 399; Herbert Hoover, The Memoirs of Herbert Hoover. Volume II. The Cabinet and the Presidency, 1920-1933 (New York, 1952), pp. 101-108; Herbert Hoover, Memorirs, I, p. 22; Herbert Hoover, Further Addresses Upon the American Road, 1938-1940 (New York, 1940), pp. 4, 42, 60-61, 201, and 211. 
it had important obligations to fulfill. The federal government was to be the arbiter and coordinator of the interest-group state. By inspiring the creation of cooperatively-controlled, voluntary interest groups, by arbitrating and negotiating their differences for them, and by regulating their activities through committees of government officials and private citizens, the federal government could guarantee the survival of the noncoercive, individualistic, progressive society. ${ }^{5}$

At the same time, Hoover believed that the main responsibility for maintaining economic prosperity and protecting the consuming public rested on the shoulders of the federal government. Rather than ignore the ups and downs of the business cycle, as previous presidential administrations had done, the federal government must underwrite the twin goals of economic growth and full employment. Herbert Hoover clearly recognized that his American Individualism, like progressive and idealistic philosophies in general, depended upon progress and economic expansion. ${ }^{6}$ Any indications of chronic imperfection or inherent corruption in the social structure or political economy would easily destroy any idealistic world view. In the case of American Individualism, prosperity was the Achilles heel. As long as the economy continued to grow and the standard of living increased for the majority of Americans, the public would tolerate and even revere American Individualism. Hoover was always keenly aware of this economic dimension to his political philosophy. In 1922 he wrote:

That high and increasing standards of living and comfort should be the first of considerations in public mind and in government needs no apology. We have long since realized that the basis of an advancing civilization must be a high and growing standard of living for all the people, not for a single class; that education, food, clothing, housing, and the spreading use of what we often term nonessentials, are the real fertilizers of the soil from which spring the finer flowers of life.

Ever since his experiences directing the Commission on Belgium Relief during World War I Hoover had realized that the

${ }^{5}$ William S. Myers, State Papers, I, p. 382; Herbert Hoover, American Individualism, pp. 15-17, 51-55; George I. Gay and H. H. Fischer, Public Relations of the Commission for Relief in Belgium: Documents. Volume II (Stanford, 1929), pp. 268-269.

${ }^{6}$ For an intriguing analysis of the idea of progress in the late nineteenth and early twentieth centuries, see David W. Noble, The Paradox of Progressive Thought (Minneapolis, 1958).

'Herbert Hoover, American Indvidualism, pp. 32-33. 
social and economic foundations of idealism were fragile and tenuous; concepts of freedom, democracy, and progress were predicated on the persistance of economic prosperity and its accompanying political stability. In the absence of economic prosperity, political stability would be difficult to maintain, and idealism would be crushed by fear and skepticism. Consequently, the crucial objective of the United States government must be economic growth, for it and it alone could successfully preserve the spirit of American Individualism:

Our economic system is but an instrument of the social advancement of the American people. It is an instrument by which we add to the security and richness of life of every individual. It by no means comprises the whole purpose of life, but it is the foundation upon which can be built the finer things of the spirit. Increase in enrichment must be the objective of the Nation, not decrease.

As far as Hoover was concerned, once economic degeneration of a chronic dimension set in, then the foundations of political stability and of the social structure would decay. Idealism, the final brick in a pyramid composed of the economic system, the political framework, and the social structure, would eventually dissolve into bitterness and violence under the impact of social revolution and economic depression. For Hoover, the "full blossom of liberty requires a reasonable confidence by the individual in his economic security." ${ }^{9}$ By virtue of its breadth and its resources, the federal government would obviously be the crucial element in preserving prosperity and stability.

At the same time, however, Hoover remained keenly aware, even obsessed, with the threat government posed to American Individualism. Possessing a sharp and tragically prophetic understanding of the dynamics of the modern bureaucratic state, Hoover was simultaneously reluctant to embark on new governmental programs involving anything more than organizing and stimulating the voluntary efforts of private interest groups or restricting the activities of any amoral, aggressive economic units. He realized that because of the massively complex affairs of an industrial society, certain regulatory responsibilities had been assumed by the government, making it the most potent element in American life. He accepted that as an inevitability of modern life, and even

${ }^{8}$ William S. Myers, State Papers, I, p. 384.

${ }^{\circ}$ Herbert Hoover, Further Addresses on the American Road (New York, 1941), p. 202. 
believed that in stimulating cooperation and in curbing abuses in the economic world, the government could actually strengthen the nation's fundamentally beneficient social system. His greatest fear, however, was that the regulatory state could not be contained within the parameters which American Individualism prescribed. The impulses to further expand the authority of the government were dangerous and irresponsible. Once created, new governmental programs could be dismantled only with great difficulty, principally because each program created a political constituency dedicated to its perpetuation. Modern bureaucratic organizations possessed almost insatiable and irresistable drives for survival and expansion. The last thing Hoover wanted was for the federal government to become the controlling element in American life. ${ }^{10}$

In fact, Hoover sustained throughout his life a nightmarish yet prophetic fear that someday a "corporate state" would develop in the United States. His acquaintance with the broad themes of recent American history had made him keenly aware of the growing power being exerted by the functional interest groups of the economy. Ever since the onset of the Industrial Revolution more and more power in virtually every sector of the economy had become concentrated in the hands of the largest organizations, be they the big labor unions, the most powerful farmers' groups, or in the supercorporations. That trend had accelerated in the 1920s. The president understood the dynamics of that growth and concentration, and even praised the steady economic growth the system had undergone. At the same time, he recognized the need for the regulatory state to protect the public against any arbitrary and hostile decisions by these functional interest groups. ${ }^{11}$

But it was in the potential of the regulatory state that Hoover envisioned danger. The decisions made by the regulatory activities of the federal government constituted an intangible and perhaps even a capricious threat to the domain of those powerful groups. To offset their sense of dependence on the government, the president believed that the leaders of America's great interest groups would feel compelled, in the name of their own sover-

${ }^{10}$ Herbert Hoover, The Challenge to Liberty, pp. 56-60, 115; Herbert Hoover, Memoirs, II, p. 71.

"Herbert Hoover, American Individualism, pp. 41-45, 52-54; William S. Myers, State Papers, I, pp. 502-504. 
eignty, to either eliminate or to control the decisions of the state. Success in that endeavor by any of the groups, Hoover feared, would threaten the very foundations of American Individualism. He envisioned several dangerous possibilities. If, for example, the labor unions managed to secure control of the state, socialism would come to dominate America. If, on the other hand, the supercorporations assumed control of political power, the United States would gradually develop into a fascist state. Neither alternative was acceptable; consequently, the federal government had to be careful about the processes it used to regulate the economy, and about the personnel it used to staff the bureaucratic apparatus. ${ }^{12}$

Because the regulatory responsibilities of the federal government in a complex industrial economy had to be, in the name of administrative efficiency, exercised by executive rather than legislative authority, Hoover realized that political and administrative power would accumulate in the hands of the executive branch of the government. Congress would consequently cease to be an effective check and balance on the presidency, instead becoming merely an administrative satellite of the more powerful executive bureaucracy. The most dangerous possibility of all, in Hoover's mind, would grow out of the interplay between the necessities of economic growth and governmental regulation; a dangerous symbiotic relationship between the powerful interest groups and the executive bureaucracy would develop, one which could almost stand immune from the political and electoral process because of the impotency of the Congress. Eventually, Hoover feared that the crucial mechanisms of bureaucratic regulation would come to be dominated by the very interest groups the state was designed to control. Such a relationship, in which economic and political power had come to be manipulated by an oligarchical coalition of the largest functional groups, would spell the death of American liberalism, because access to both political and economic authority could be restricted by a small coterie of influential economic power brokers. Contrary to the main tenets of American Individualism, ability and ambition would then become irrelevancies as far as advancement within the system was concerned. ${ }^{13}$

Finally, Hoover concluded that after the spirit of Amerian lib-

${ }^{12}$ Herbert Hoover, American Individualism, pp. 37-38.

${ }^{13}$ Herbert Hoover, The Challenge to Liberty, pp. 67-69, 130-131. 
eralism had been dissipated by the dynamics of the "corporate state," there would still exist powerful impulses to destroy even the formal institutions of American government. If the federal government ever forged an alliance with any of the groups, or with a coalition of the largest unions and corporations, the very processes of economic life would shortly lead to a totalitarian form of political life. The federal government must never become a competitive participant with the major functional groups in the economy, usurping economic functions normally left to private institutions, because in addition to the characteristic inefficiency of large political bureaucracies, totalitarian political impulses would accompany direct economic intervention. If the federal government engaged in direct economic intervention, sooner or later it would commit economic blunders and would resent carrying the burden of political responsibility for those mistakes. The persistance of such resentment would lead eventually to tyrannical political tactics. In the first place, the economic elite would be perfectly willing, even anxious, to finance the political campaigns of the executive incumbents and their bureaucratic allies. With such massive funding, the existing administrations would be able to legitimately defeat less wealthy opponents who intended to assault the system. Secondly, in order to guarantee their own political tenure and undermine those who were critical of their economic decisions, the incumbent politicians and bureaucrats would be tempted, and then induced by their own vanities and survival instincts, to manipulate and then to subvert the electoral process. Under such circumstances, the interest group state would have eliminated all intangibles from its planning formula; would have effectively insulated itself from all criticism; and would have absolutely closed itself to all nonmembers of the oligarchy. Individualism and equality of opportunity, along with the form and substance of the American dream, would be destroyed. ${ }^{14}$

${ }^{14}$ Ibid., pp. 60, 79, and 225; Herbert Hoover, American Individualism, pp. 37-38; Herbert Hoover, Memoirs, II, p. 304; William S. Myers, The State Papers and Other Public Writings of Herbert Hoover. Volume II (New York, 1934), p. 425; Herbert Hoover, Addresses Upon the American Road, 1941-1945 (New York, 1946), p. 223; Herbert Hoover, Addresses Upon the American Road, 19451948 (New York, 1949), pp. 45, 50; Herbert Hoover, Addresses Upon the American Road, 1948-1950 (Stanford, 1951), p. 20. 
The personal philosophy of Herbert Hoover consequently possessed two powerful ideological tensions, two Jeckyl and Hyde syndromes over the beneficience of the nation's economic interest groups and over the nature of the federal government. The functional interest groups had, on the one hand, brought economic supremacy to the United States, a productive capacity and standard of living unique in human history. But at the same time, they contained within themselves the impulses to destroy the substance of American life. As a result, the future of American Individualism rested upon the ability of the executive branch of the government to control the exercise of both bureaucratic and economic power. That necessity, however, activated the second tension in his philosophy, for the federal government faced the ominous challenge of regulating without controlling, of stimulating the economy without coercing the activities of the country's economic interest groups. When Hoover assumed control of the executive branch in 1929, he looked upon himself as both a political and economic specialist leading the country down the middle road between the right and the left, between laissez-faire on the one hand, and socialism or fascism on the other. It was that middle road, he believed, which would resolve that dual ideological tension in his political philosophy. Unfortunately for his career and reputation, that middle road narrowed into a tightrope of depression-inspired panic and suffering.

In 1929, the unthinkable occurred; while Hoover ascended to the presidency, the economy descended into the depths of the greatest and most devastating depression in the country's history. Visions of political conflict, then social instability, and ultimately even revolution passed through the president's mind. The dilemma and ordeal of Herbert Hoover revolved around the economic erosion of American Individualism's philosophical rationale. The Great Depression instantly stimulated the second tension in his thought, for he was forced to consider literally hundreds of demands for massively expanding the power and scope of the federal government. On the one hand, his understanding of the importance of economic security and prosperity as prerequisites for political stability persuaded him to consider massive federal economic intervention; but on the other hand, his fears of the dangers of massive political and administrative bureaucracies in 
Washington prevented him from granting dictatorial economic authority or even massive financial resources to the federal government. In the long run, the president's fears came to overwhelm his understanding of the relationship between political tranquility and economic security; massive federal intervention was not forthcoming. He was conscious of the choice he made, and guilty of nothing more than farsightedness. His fears of the long-range consequences of governmental activism and insensitive bureaucracies wedded by mutual interest to the powerful economic elites have been fulfilled in American life. Unfortunately for his political career and historical reputation, Hoover's ultimate vision of the "corporate state" left him unable to clearly focus on the terribly immediate problems of financial collapse, and unable to initially accept the inevitability of direct federal support of the nation's relief machinery. During a period of relative prosperity, Herbert Hoover would likely have been one of America's greatest presidents, for his sophisticated understanding of corporate, industrial and bureaucratic realities would have permitted him to simultaneously regulate the economy and restrain the federal government. The Great Depression, however, upset his hopes. While he worried about the future substance of American institutions, seventy million of his fellow citizens worried about tomorrow night's meal and the next month's rent. The stark immediacy of their needs would render Hoover's fears irrelevant to his own generation, ultimately transforming his nightmares into reality. In recent years the United States has witnessed the development of a complex and insensitive federal bureaucracy, of illegal and corrupting relationships between the business and political communities, and of subversive electoral and political activities by those holding positions of power. Herbert Hoover's greatest political enemy, ironically, proved to be his own insight; he was the premiere victim of his own vision. 
Copyright of Annals of Iowa is the property of State of Iowa, by \& through the State Historical Society of Iowa and its content may not be copied or emailed to multiple sites or posted to a listserv without the copyright holder's express written permission. However, users may print, download, or email articles for individual use. 